\title{
Protective effect of 3, 3'-Diindolylmethane encapsulated chitosan nanoparticles prop up with lipid metabolism and biotransformation enzymes against possible mammary cancer
}

\author{
Stainsloss Isabella, Sankaran Mirunalini* \\ Department of Biochemistry and Biotechnology, Annamalai University, Chidambaram, Tamil Nadu, India.
}

\begin{tabular}{|c|c|}
\hline ARTICLE INFO & ABSTRACT \\
\hline Article history: & \multirow{12}{*}{$\begin{array}{l}\text { 3, 3'-Diindolylmethane (DIM) a dietary indole compound occur naturally as glucosinolate conjugates in } \\
\text { Brassica vegetables has been extensively studied for its anticancer action both in vitro and in vivo models. Due } \\
\text { to, its poor water solubility, its absorption upon oral administration has limited its clinical development. In order } \\
\text { to improve its therapeutic value, nanoparticle based drug delivery system has paved way to revolutionize cancer } \\
\text { for an effective treatment. In the current study, we have chosen a non toxic capping agent chitosan for the } \\
\text { synthesis of DIM encapsulation. 7, 12- dimethylbenz (a) anthracene (DMBA) were used as chemical carcinogen } \\
\text { to induce mammary cancer on Female Sprague Dawley rats. We observed increased levels of Cyt P } 450 \text {, Cyt-b5 } \\
\text { and drop off levels of GST and GR enzymes noticed in mammary and liver tissues of DMBA induced rats. } \\
\text { Furthermore, the correlation between lipids and lipoproteins has been associated with the risk of breast cancer. } \\
\text { Thus, the elevated levels of total cholesterol (TG), phospholipids (PL), triglycerides (TG) and free fatty acids } \\
\text { (FFA) in plasma, liver and mammary tissues of DMBA induced tumor bearing rats. Moreover, very low density } \\
\text { lipoprotein (VLDL) and low density lipoprotein (LDL) were increased and high density lipoprotein (HDL) } \\
\text { levels were decreased in tumor bearing rats. Whereas, oral administration of DIM@ @S-NP } 0.5 \mathrm{mg} / \mathrm{kg} \text { b.wt were } \\
\text { significantly reverted back to near normal level of Phase I, Phase II, lipids and lipoproteins. } \\
\text { Our finding demonstrated that nanoencapsulation DIM @CS-NP proved a potent chemotherapeutic agent which } \\
\text { may have a major impact in mammary cancer. }\end{array}$} \\
\hline Received on: $13 / 01 / 2017$ & \\
\hline Accepted on: $24 / 02 / 2017$ & \\
\hline Available online: $30 / 03 / 2017$ & \\
\hline & \\
\hline Breast cancer, DIM, DMBA, & \\
\hline & \\
\hline Cytochrome b5. & \\
\hline & \\
\hline & \\
\hline & \\
\hline & \\
\hline
\end{tabular}

\section{INTRODUCTION}

Among cancer, breast cancer is one of the most somber tribulations. In numerous countries, it is a foremost health anxiety and most important cause of death among women (Kumar et al., 2016). Breast cancer incidence reports that, varies extensively within regions, and countries and all over the world (Komenaka et al., 2010). Environmentally ubiquitous set of compounds like polycyclic aromatic hydrocarbons (PAHs), are formed during unfinished incineration of organic substances. Numerous PAHs have been classified as possible human

\section{* Corresponding Author}

Dr. S. Mirunalini, Assistant Professor, Department of Biochemistry and Biotechnology, Annamalai University, Annamalai Nagar - 608 002, Tamil Nadu, India.Email: mirunasankar @gmail.com Tel: 914144238343 , Fax: 914144238343. carcinogens. Various studies show that, the formation of carcinogen is because of DNA adducts in human / rat tissues through genotoxic PAHs. In breast cancer higher amounts of PAHDNA adducts have been found as compared to normal tissues (Chan et al., 2002). In addition, these chemical carcinogens need metabolic activation by phase I enzymes, which gets detoxify by phase II enzymes.

The metabolic equilibrium among phase I and phase II enzymes are considered to be an imperative factor in determining the susceptibility of cancer (Nebert et al., 1996). The causative link between fat, obesity, lifestyle, particularly lipids and lipoproteins are the most important source coupled with the elevated occurrence of breast cancer. Certainly, lipids take steps as a metabolic fuel in the development of breast cancer cells (Kuhajda et al., 2000). Numerous, epidemiological evidence has exposed 
that the diet rich in fruits, vegetables, low in fat and proteins are connected with a lower risk of cancer. Furthermore, it was found that consumption of cruciferous vegetables increases and diminishes the prevalence of breast cancer in women. These vegetables contain glucosinolates, which break into several products, mainly indole-3-carbinol (I3C). I3C converted into polymeric products, in a low $\mathrm{pH}$ environment among which, 3, 3'Diindolylmethane (DIM) is one of the product (Paltsev et al., 2013). How be it, its scientific records as an anticancer agent in numerous preclinical models, it acts as a potential pharmaceutical agent, which is extremely poor in bioavailability due to its low solubility and high lipophilicity in in vivo. Luo et al. also synthesis the encapsulation of I3C and DIM using with Zein/ CMCS nanoparticles and provide controlled release of food/pharmaceutical applications (Yangchao et al., 2013). So such approaches made it possible to develop a great interest in scrutinizing the encapsulation of DIM in nanoparticles could endow with bioavailability, sustained release property and improved their stability on harsh environmental situation. Various anticancer drugs have been encapsulated in various polymeric nanoparticles to increase their activity by reducing side effect. A variety of biodegradable polymeric nanoparticles have been extensively used for controlled release of active molecules and drugs. Hence, Chitosan is considered one of the interesting imperative drug carriers; which control the drug release to the physiological requirements of the body, as in the case of hormone release (Duncan, 2003). Hence, the current investigation emphasizes the alterations in the lipid metabolism, phase I, phase II enzyme and histopathologically analysis of mammary tissues and liver in 3, 3'-Diindolylmethane encapsulated Chitosan nanoparticles (DIM@CS-NP) on DMBA induced Sprague Dawley rats. In our laboratory, we scrutinized the 3, 3'-Diindolylmethane encapsulated Chitosan nanoparticles (DIM@CS-NP) on DMBA induced Sprague Dawley rats by evaluating oxidant, antioxidant and histophathological changes (Isabella et al., 2016).

\section{MATERIALS AND METHODS}

\section{Chemicals}

3,3'- Diindolymethane, Chitosan $(\mathrm{MW}=60-90 \mathrm{kDa}$; degree of deacetylation 85\%), sodium tripolyphosphate (TPP), 7, 12-Dimethylbenz (a) anthracene (DMBA) and all other chemicals were purchased from Sigma (St. Louis, MO, USA). Reagent kits for TC, TG and HDL-C were purchased from Agappe Diagnostics, Ernakulam, India.

\section{Preparation and characterization of DIM@CS-NP}

DIM@CS-NP and CS-NP was synthesized by ionic gelation method using TPP as a gelating agent (Elzatahry AA et al.2008 and Arul mozhi et al., 2013). The lyophilized samples (DIM@CS-NP, CS-NP) and free DIM were characterized by UV, FT-IR analysis, Zeta Sizer, Particle size analyzer, SEM analysis, Thermogravimetric analysis, In vitro drug release, Pharmacokinetic study.

\section{Rats and diet}

This study was approved by the Institutional Animal Ethics Committee (IAEC), regulated by the Committee for the Purpose of Control and Supervision of Experimental Animals (CPCSEA) (Reg No. 160/1999/CPCSEA and Proposal No. 1123). Before starting the experiments the rats were acclimatized for a week. Female Sprague Dawley rats six to seven weeks old weighed 130-150 g, were obtained from National Institute of Nutrition, Hyderabad, India. Rats were maintained in the Central Rat House of Rajah Muthiah Medical College and Hospital, Annamalai University, Chidambaram, Tamil Nadu, India. The rats were maintained under temperature of $24 \pm 2{ }^{\circ} \mathrm{C}$, humidity $(50 \pm$ $10 \%$ ) and $12 \mathrm{~h} \mathrm{light/dark} \mathrm{cycle} \mathrm{also} \mathrm{feed} \mathrm{and} \mathrm{water} \mathrm{provided.}$

\section{Tumor induction}

The present investigation DMBA was used as a chemical carcinogen. Mammary tumor induced by a single subcutaneous injection of $25 \mathrm{mg} / \mathrm{kg}$ b.wt of DMBA dissolved in $1 \mathrm{~mL}$ emulsion of sunflower oil $(0.75 \mathrm{~mL})$ and physiological saline $(0.25 \mathrm{~mL})$ (Welsch, 1985).

\section{Experimental design}

The experimental period 16 weeks. The rats were divided into six groups with six rats in each group and were given the dose regimen as follows $(n=6)$. Group 1 rats served as control. Group 24 rats were received $25 \mathrm{mg} / \mathrm{kg}$ b.wt of DMBA. In addition group 3 and 4 were treated with different doses of bare DIM and DIM @ CS-NP (10, $0.5 \mathrm{mg} / \mathrm{kg}$ b.wt) respectively. Group 5 and 6 were received bare DIM and DIM @ CS-NP (10, $0.5 \mathrm{mg} / \mathrm{kg}$ b.wt) and serve as drug control. The doses were fixed, based on a dose dependent study that we have already examined in our lab (Isabella S et al., 2016), end of the experiment all the rats were fasted overnight and sacrificed by cervical decapitation. Blood were collected in heparinised tubes and the plasma was used for the further analysis. Mammary and liver tissues were separated without delay and washed well with ice-cold saline and homogenized in Tris-HCL buffer (0.1 M, pH 7.4).

\section{Histopathological examination}

The histopathology analysis of liver tissue in experimental rats were sliced and immersed at once in $10 \%$ buffered formalin solution for fixation and dehydrated with graded ethanol solutions from $50 \%$ to $100 \%$ and then embedded in paraffin. The tissue sections of $5 \mathrm{~mm}$ in thickness were cut and stained with haematoxylin and eosin and the slides were observed in the microscope.

\section{BIOCHEMICAL ANALYSIS}

Phase I and Phase II enzymes.

Liver and mammary tissues microsomes were isolated by the methods of Hanioka et al (Hanioka et al., 1997). The microsomal protein content was estimated by the method of Lowry (1951). Cyt P 450 and Cyt b5 levels in mammary and liver tissues 
microsomes were estimated by the method of Omura and Sao (Omura and Sato 1964). GST activities in homogenate mammary and liver tissues were assayed by the method of Hagig et al., (Habig et al., 1974). GR activities in mammary and liver tissues were assayed the method of Calberg and Mannervik (Carlberg and Mannervik 1985).

\section{Lipid profile}

Liver extraction was done by the method of Folch et al., (Folch et al., 1957) Total cholesterol, Triglycerides, Free fatty acid and Phospholipids were estimated plasma and tissue by the methods of Allain et al., (Allain et al., 1974), Foster and Dunn (Foster and Dunn 1973), Falholt et al., (Falholt et al., 1973), Zilversmit and Davis (Zilversmit and Davis 1950) using a reagent kit respectively.

Plasma high- density lipoprotein - C (HCL-C) was estimated by the method of Wilson and springer using a reagent kit (Wilson, 1973). Low density lipoprotein - C (LDL-C) and very low density lipoprotein $-\mathrm{C}$ (VLDL-C) were calculated by Friedwald's formula (Friedewald, 1972). LDL-C = TC $-($ HDL-C + VLDL-C), VLDL- C= TG/5.

\section{Statistical analysis}

A statistical analysis was carried out using SPSS 17 (SPSS, Inc., Chicago) statistical package. The statistical data were shown as mean \pm standard deviation (SD). One way analysis of variance (ANOVA) followed by Duncan Multiple Range Test (DMRT) comparison method was used to associate the difference between the variables. The data were expressed significant if $p$ values are less than 0.05 .

\section{RESULTS}

\section{Effect of DIM and DIM@CS- NP on the body weight and tumor volume}

We summarized in table 1 , the body weights were found to be significantly $(p<0.05)$ dwindled in (Group II) tumor bearing rats. Dissimilarly, in tumor bearing rats treated with (Group III) DIM 10mg/kg b.wt and (Group IV) DIM@CS-NP 0.5 mg/kg b.wt significantly $(p<0.05)$ improved the body weight when compared to (Group II) DMBA induced rats. However, no significant changes were observed in DIM 10mg/kg b.wt and DIM @ CS-NP $0.5 \mathrm{mg} / \mathrm{kg}$ b.wt alone treated (Group V and Group VI) rats when compared to (Group I) control rats.

Fig. 1 shows tumor volume of control and experimental rats. There was significantly $(p<0.05)$ increased in tumor volume was observed in (Group II) DMBA induced rats, in this group volume of the tumor volume is $23.11 \mathrm{~mm}$. Whereas, in tumor bearing rats treated with DIM 10mg/ $\mathrm{kg}$ b.wt (Group III) and DIM@CS-NP 0.5mg / kg b.wt (Group IV) was a significant ( $p<$ 0.05 ) decreased in tumor volume 11.76 and $5.62 \mathrm{~mm}$ were found respectively as compared to (Group II) DMBA induced rats. However, no changes were observed in DIM $10 \mathrm{mg} / \mathrm{kg}$ b.wt (Group V) and DIM@CS-NP 0.5 mg/kg b.wt (Group VI) alone treated rats compared with (Group I) control rats. DIM@CS-NP $0.5 \mathrm{mg} / \mathrm{kg}$ b.wt was found to be effective as compare to DIM $10 \mathrm{mg} / \mathrm{kg}$ b.wt.

Table 1: Effect of DIM and DIM@CS-NP on the body weight and tumor volume of control and experimental rats.

\begin{tabular}{|c|c|c|c|}
\hline Groups & Initial & Final & $\begin{array}{c}\begin{array}{c}\text { Tumor } \\
\text { volume } \\
(\mathbf{m m 3}) / \text { rat }\end{array} \\
\end{array}$ \\
\hline Control & $135.20 \pm 12.6^{\mathrm{a}^{*}}$ & $165.00 \pm 12.3^{\mathrm{a} * *}$ & - \\
\hline $\begin{array}{l}\text { DMBA } \\
\text { DMBA+DIM } 10 \mathrm{mg} /\end{array}$ & $140.30 \pm 13.03^{\mathrm{a}^{*}}$ & $95.20 \pm 8.2^{\mathrm{b}}$ & $23.11^{\mathrm{b}^{*}}$ \\
\hline & $141.00 \pm 13.63^{\mathrm{a}^{*}}$ & $132.70 \pm 12.2^{\mathrm{c}}$ & $11.76^{\mathrm{c}^{*}}$ \\
\hline $\mathrm{NP} 0.5 \mathrm{mg} / \mathrm{kg}$ b.wt & $145.00 \pm 13.01^{\mathrm{a}^{*}}$ & $157.00 \pm 12.6^{\mathrm{a}^{* * *}}$ & $5.62^{\mathrm{d}}$ \\
\hline $\begin{array}{l}\text { DIM } 10 \mathrm{mg} / \mathrm{kg} \text { b.wt } \\
\text { DIM@CS-NP } 0.5 \mathrm{mg} /\end{array}$ & $135.50 \pm 12.11^{\mathrm{a}^{*}}$ & $163.00 \pm 15.7^{\mathrm{a}^{* *}}$ & - \\
\hline kg b.wt & $135.60 \pm 12.61^{\mathrm{a}^{*}}$ & $164.00 \pm 15.9^{\mathrm{a}^{* *}}$ & - \\
\hline \multicolumn{4}{|c|}{$\begin{array}{l}\text { Values are expressed as mean } \pm \text { SD for six rats in each group. Values not share } \\
\text { a common superscripts differ significantly at a } p \text { value of }<0.05(D M R T) \text {. } \\
\text { Tumor volume was measured using the formula } V=4 / 3 \pi\left(D_{1 / 2}\right)\left(D_{2 / 2}\right)\left(D_{3 / 2}\right) \text {, } \\
\text { where } D_{1}, D_{2} \text { and } D_{3} \text { are the three diameters (in mm) of the tumor. a*: is initial } \\
\text { body weight, a**: Final body weight of control group, b: DMBA positive } \\
\text { control, c: DMBA positive control treated with } 0.5 \mathrm{mg} / \mathrm{kg} \text { b.wt, b*: Tumor } \\
\text { weight of DMBA positive control group, c*: DMBA positive control treated } \\
\text { with DIM } 10 \mathrm{mg} / \mathrm{kg} \text { b.wt, d: DMBA positive control treated with DIM@CS- } \\
\text { NP } 0.5 \mathrm{mg} / \mathrm{kg} \text { b.wt. }\end{array}$} \\
\hline
\end{tabular}

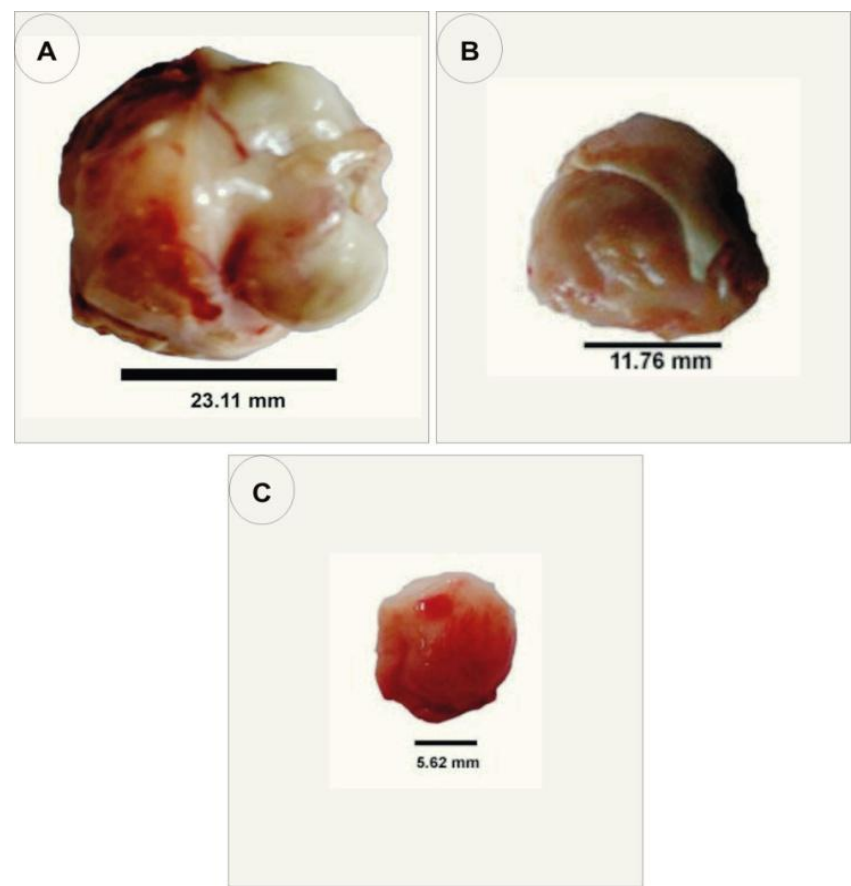

Fig. 1: Anti-tumor effect of DIM and DIM@CS-NP treatment on DMBA induced mammary tumor bearing in rats compared with DMBA Induced groups. (A) Mammary tumor bearing rats. (B) Mammary tumor bearing rats treated with DIM $10 \mathrm{mg} / \mathrm{kg}$ b.wt. (C) Mammary tumor bearing rats treated with DIM@CS-NP 0.5mg/kg b.wt.

\section{Effect of DIM and DIM @ CS-NP on biotransformation enzyme levels}

Table 2 and 3 shows the levels of phase I (Cyt P 450 and Cyt-b5) and phase II (GST, GR) enzyme levels in liver and mammary tissues microsomes of the experimental rats. The levels 
of Cyt P 450 and Cyt-b5 were significant $(p<0.05)$ increased, the activities of GST and GR were significantly $(p<0.05)$ reduced on DMBA induced (Group II) rats when compared with the (Group I) control rats. The administration of DIM@CS-NP 0.5mg/kg b.wt (Group IV) tumor bearing rats treated with were significantly $(p<$ $0.05)$ decreased in phase I enzymes and increased in phase II enzymes when compared with DIM $10 \mathrm{mg} / \mathrm{kg}$ b.wt (Group III) rats. However, there was no significantly differ in the rats administer with DIM 10 mg/kg b.wt (Group V) and DIM@CS-NP 0.5mg/kg b.wt (Group VI) alone when compared to control (Group I) rats. In predominantly DIM@CS-NP $0.5 \mathrm{mg} / \mathrm{kg}$ b.wt more effective as compared DIM $10 \mathrm{mg} / \mathrm{kg}$ b.wt.

Table 2: Effect of DIM and DIM@CS-NP on biotransformation enzyme levels in liver microsomes of control and experimental rats.

\begin{tabular}{lcccc}
\hline Group & Cyt P 450 & Cyt b5 & GST & GR \\
\hline Control & $0.76 \pm 0.05^{\mathrm{a}}$ & $0.55 \pm 0.03^{\mathrm{a}}$ & $1.42 \pm 0.07^{\mathrm{a}}$ & $26.21 \pm 1.90^{\mathrm{a}}$ \\
DMBA & $1.51 \pm 0.09^{\mathrm{b}}$ & $0.87 \pm 0.06^{\mathrm{b}}$ & $0.82 \pm 0.04^{\mathrm{b}}$ & $13.56 \pm 1.10^{\mathrm{b}}$ \\
$\begin{array}{l}\text { DMBA+DIM } \\
\text { 10 mg/ kg b.wt }\end{array}$ & $1.23 \pm 0.08^{\mathrm{c}}$ & $0.76 \pm 0.05^{\mathrm{c}}$ & $1.16 \pm 0.08^{\mathrm{c}}$ & $18.52 \pm 1.50^{\mathrm{c}}$ \\
$\begin{array}{l}\text { DMB A+DIM@CS- } \\
\text { NP 0.5mg/ kg b.wt }\end{array}$ & $0.89 \pm 0.05^{\mathrm{d}}$ & $0.64 \pm 0.04^{\mathrm{d}}$ & $1.29 \pm 0.06^{\mathrm{d}}$ & $21.67 \pm 1.31^{\mathrm{d}}$ \\
$\begin{array}{l}\text { DIM 10 mg/ kg b.wt } \\
\text { DIM@ CS-NP 0.5 }\end{array}$ & $0.79 \pm 0.04^{\mathrm{a}}$ & $0.57 \pm 0.03^{\mathrm{a}}$ & $1.39 \pm 0.07^{\mathrm{a}}$ & $25.82 \pm 1.71^{\mathrm{a}}$ \\
mg/ kg b.wt & $0.77 \pm 0.04^{\mathrm{a}}$ & $0.56 \pm 0.03^{\mathrm{a}}$ & $1.40 \pm 0.07^{\mathrm{a}}$ & $26.10 \pm 1.80^{\mathrm{a}}$ \\
\hline
\end{tabular}

Cyt P450- nmol/mg microsomal protein. Cyt b5 - nmol/mg microsomal protein. GST $-\mu \mathrm{mol}$ of CDNB-GSH conjugate formed/mg microsomal protein/min. GR $-\mu \mathrm{mol}$ of NADPH oxidized/mg microsomal protein/min. Values are expressed as mean \pm SD for six rats in each group. Values not sharing a common superscript differ significantly at $p<0.05$ (DMRT). a: Control group, b: DMBA positive control group, c: DMBA positive control group treatment with DIM $10 \mathrm{mg} / \mathrm{kg}$ b.wt, d: DMBA positive control group treatment with DIM@CS-NP 0.5mg/kg b.wt.

Table 3: Effect of DIM and DIM@CS-NP on biotransformation enzyme levels in mammary tissue of control and experimental rats.

\begin{tabular}{llccc}
\hline Group & CYP450 & Cyt b5 & GST & GR \\
\hline Control & $0.95 \pm 0.05^{\mathrm{a}}$ & $0.64 \pm 0.04^{\mathrm{a}}$ & $1.26 \pm 0.07^{\mathrm{a}}$ & $3.55 \pm 0.26^{\mathrm{a}}$ \\
DMBA & $1.43 \pm 0.07^{\mathrm{b}}$ & $0.95 \pm 0.55^{\mathrm{b}}$ & $0.70 \pm 0.04^{\mathrm{b}}$ & $1.36 \pm 0.07^{\mathrm{b}}$ \\
DMBA+DIM & & & & \\
10 mg/ kg b.wt & $1.28 \pm 0.06^{\mathrm{c}}$ & $0.80 \pm 0.06^{\mathrm{c}}$ & $0.97 \pm 0.05^{\mathrm{c}}$ & $2.17 \pm 0.10^{\mathrm{c}}$ \\
DMBA+DIM@CS-NP & & & & \\
0.5mg/ kg b.wt & $1.19 \pm 0.07^{\mathrm{d}}$ & $0.72 \pm 0.04^{\mathrm{d}}$ & $1.16 \pm 0.07^{\mathrm{d}}$ & $3.01 \pm 0.21^{\mathrm{d}}$ \\
DIM 10 mg/ kg b.wt & $0.98 \pm 0.06^{\mathrm{a}}$ & $0.61 \pm 0.05^{\mathrm{a}}$ & $1.21 \pm 0.06^{\mathrm{a}}$ & $3.39 \pm 0.19^{\mathrm{a}}$ \\
DIM@CS-NP & & & & \\
$0.5 \mathrm{mg} / \mathrm{kg}$ b.wt & $0.96 \pm 0.08^{\mathrm{a}}$ & $0.63 \pm 0.05^{\mathrm{a}}$ & $1.25 \pm 0.05^{\mathrm{a}}$ & $3.53 \pm 0.24^{\mathrm{a}}$ \\
\hline
\end{tabular}

Cyt P450- nmol/mg microsomal protein. Cyt b5 - nmol/mg microsomal protein. GST $-\mu \mathrm{mol}$ of CDNB-GSH conjugate formed/mg microsomal protein/min. GR $-\mu \mathrm{mol}$ of NADPH oxidized/mg microsomal protein/min. Values are expressed as mean \pm SD for six rats in each group. Values not sharing a common superscript differ significantly at $p<0.05$ (DMRT). a: Control group, b: DMBA positive control group, c: DMBA positive control group treatment with DIM $10 \mathrm{mg} / \mathrm{kg}$ b.wt, d: DMBA positive control group treatment with DIM@CS-NP 0.5mg/kg b.wt.

\section{Effect of DIM and DIM@CS-NP on lipid profile in liver, mammary tissue and plasma}

The lipid levels of (Total cholesterol, Phospholipids, Triglycerides and Free Fatty Acids) liver, mammary tissues and plasma of experimental rats shown in table 4,5 and 6 correspondingly. The levels of total cholesterol, phospholipids, triglycerides and free fatty acids in liver, mammary tissues and plasma were significantly increased $(p<0.05)$ in DMBA induced (Group II) rats when compared to (Group I) control rats. In tumor bearing rats treated with DIM@CS-NP $0.5 \mathrm{mg} / \mathrm{kg}$ b.wt (Group IV) was found to be more effective than DIM 10mg/kg b.wt (Group III). No changes were observed significantly in drug control (Group V) and (Group VI) rats when compared to control (Group I) rats.

Table 4: Effect of DIM and DIM@CS-NP on lipid profile in liver of control and experimental rats.

\begin{tabular}{lllll}
\hline Group & $\begin{array}{c}\text { TG } \\
(\mathbf{m g} / \mathbf{g})\end{array}$ & $\begin{array}{c}\text { TC } \\
(\mathbf{m g} / \mathbf{g})\end{array}$ & $\begin{array}{c}\text { PL } \\
(\mathbf{m g} / \mathbf{g})\end{array}$ & $\begin{array}{c}\text { FFA } \\
(\mathbf{m g} / \mathbf{g})\end{array}$ \\
\hline Control & $4.77 \pm 0.43^{\mathrm{a}}$ & $4.62 \pm 0.42^{\mathrm{a}}$ & $24.52 \pm 1.87^{\mathrm{a}}$ & $7.04 \pm 0.66^{\mathrm{a}}$ \\
DMBA & $9.78 \pm 0.84^{\mathrm{b}}$ & $8.32 \pm 0.79^{\mathrm{b}}$ & $48.30 \pm 3.92^{\mathrm{b}}$ & $15.5 \pm 1.29^{\mathrm{b}}$ \\
$\begin{array}{l}\text { DMB A+DIM } \\
\text { 10 mg/ kg b.wt }\end{array}$ & $7.69 \pm 0.61^{\mathrm{c}}$ & $6.49 \pm 0.58^{\mathrm{c}}$ & $39.40 \pm 3.29^{\mathrm{c}}$ & $12.7 \pm 0.95^{\mathrm{c}}$ \\
$\begin{array}{l}\text { DMBA+DIM@CS- } \\
\text { NP 0.5mg/ kg b.wt }\end{array}$ & $6.33 \pm 0.43^{\mathrm{d}}$ & $5.43 \pm 0.51^{\mathrm{d}}$ & $33.46 \pm 3.19^{\mathrm{d}}$ & $8.45 \pm 0.73^{\mathrm{d}}$ \\
$\begin{array}{l}\text { DIM 10 mg/ kg b.wt } \\
\text { DIM@CS-NP 0.5 }\end{array}$ & $4.80 \pm 0.38^{\mathrm{a}}$ & $4.65 \pm 0.45^{\mathrm{a}}$ & $24.57 \pm 1.92^{\mathrm{a}}$ & $7.19 \pm 0.65^{\mathrm{a}}$ \\
mg/ kg b.wt & $4.78 \pm 0.40^{\mathrm{a}}$ & $4.63 \pm 0.42^{\mathrm{a}}$ & $24.54 \pm 1.89^{\mathrm{a}}$ & $7.02 \pm 0.63^{\mathrm{a}}$ \\
\hline Vau arp
\end{tabular}

Values are expressed as mean \pm SD for six rats in each group. Values not sharing a common superscript differ significantly at $p<0.05$ (DMRT). a: Control group, b: DMBA positive control group, c: DMBA positive control group treatment with DIM $10 \mathrm{mg} / \mathrm{kg}$ b.wt, d: DMBA positive control group treatment with DIM@CS-NP $0.5 \mathrm{mg} / \mathrm{kg}$ b.wt.

Table 5: Effect of DIM and DIM@CS-NP on lipid profile in mammary tissue of control and experimental rats.

\begin{tabular}{|c|c|c|c|c|}
\hline Groups & $\begin{array}{r}\text { TG } \\
(\mathrm{mg} / \mathrm{g})\end{array}$ & $\begin{array}{r}\mathrm{TC} \\
(\mathrm{mg} / \mathrm{g})\end{array}$ & $\begin{array}{c}\mathbf{P L} \\
(\mathrm{mg} / \mathrm{g})\end{array}$ & $\begin{array}{r}\text { FFA } \\
(\mathrm{mg} / \mathrm{g})\end{array}$ \\
\hline Control & $4.22 \pm 0.37^{\mathrm{a}}$ & $4.66 \pm 0.32^{\mathrm{a}}$ & $14.96 \pm 1.26^{\mathrm{a}}$ & $13.05 \pm 1.14^{\mathrm{a}}$ \\
\hline $\begin{array}{l}\text { DMBA } \\
\text { DMBA+DIM }\end{array}$ & $9.79 \pm 0.95^{\mathrm{b}}$ & $8.25 \pm 0.67^{b}$ & $25.71 \pm 2.05^{\mathrm{b}}$ & $20.07 \pm 1.67^{\mathrm{b}}$ \\
\hline $\begin{array}{l}10 \text { mg/ kg b.wt } \\
\text { DMBA+DIM@CS- } \\
\text { NP 0.5mg/ kg b.wt }\end{array}$ & $8.86 \pm 0.86^{\mathrm{c}}$ & $6.45 \pm 0.51^{\mathrm{c}}$ & $19.52 \pm 1.43^{\mathrm{c}}$ & $\begin{array}{l}17.24 \pm 1.52^{\mathrm{c}} \\
15.24 \pm 1.53^{\mathrm{d}}\end{array}$ \\
\hline $\begin{array}{l}\text { DIM } 10 \mathrm{mg} / \mathrm{kg} \text { b.wt } \\
\text { DIM@CS-NP } 0.5 \\
\mathrm{mg} / \mathrm{kg} \text { b.wt }\end{array}$ & $4.26 \pm 0.37^{\mathrm{a}}$ & $4.70 \pm 0.40^{\mathrm{a}}$ & $15.01 \pm 1.42^{\mathrm{a}}$ & $13.10 \pm 1.22^{\mathrm{a}}$ \\
\hline $\begin{array}{l}\text { Values are expressed } \\
\text { sharing a common su } \\
\text { a: Control group, b: I } \\
\text { group treatment with } \\
\text { treatment with DIMC }\end{array}$ & $\begin{array}{l}\text { is mean } \pm \text { SD } \\
\text { erscript diffe } \\
\text { MBA positiv } \\
\text { IM } 10 \mathrm{mg} / \mathrm{k} \\
\text { CS-NP } 0.5 \mathrm{~m}\end{array}$ & $\begin{array}{l}\text { for six rats ir } \\
\text { significantly } \\
\text { control grou } \\
\text { b.wt, d: DM } \\
\text { kg b.wt. }\end{array}$ & $\begin{array}{l}\text { n each group. } \\
\text { at } p<0.05 \text { (I } \\
\text { BA positive c }\end{array}$ & $\begin{array}{l}\text { alues not } \\
\text { MRT). } \\
\text { sitive control } \\
\text { trol group }\end{array}$ \\
\hline
\end{tabular}

Table 6: Effect of DIM and DIM@CS-NP on lipid profile in plasma of control and experimental rats.

\begin{tabular}{|c|c|c|c|c|}
\hline Group & $\begin{array}{c}\text { TG } \\
(\mathrm{mg} / \mathrm{dL})\end{array}$ & $\begin{array}{c}\text { TC } \\
(\mathrm{mg} / \mathrm{dL})\end{array}$ & $\begin{array}{c}\text { PL } \\
(\mathbf{m g} / \mathbf{d L})\end{array}$ & $\begin{array}{c}\text { FFA } \\
(\mathbf{m g} / \mathbf{d L})\end{array}$ \\
\hline Control & $78.21 \pm 6.9^{\mathrm{a}}$ & $85.61 \pm 7.3^{\mathrm{a}}$ & $104.34 \pm 9.43^{\mathrm{a}}$ & $11.4 \pm 1.08^{\mathrm{a}}$ \\
\hline $\begin{array}{l}\text { DMBA } \\
\text { DMBA+DIM }\end{array}$ & $130.10 \pm 12.4^{b}$ & $142.30 \pm 13.1^{\mathrm{b}}$ & $154.37 \pm 14.62^{b}$ & $18.17 \pm 1.50^{\mathrm{b}}$ \\
\hline $\begin{array}{l}10 \mathrm{mg} / \mathrm{kg} \text { b.wt } \\
\text { DMBA+DIM @ CS- }\end{array}$ & $102.32 \pm 9.1^{\mathrm{c}}$ & $119.08 \pm 10.3^{c}$ & $135.01 \pm 12.92^{\mathrm{c}}$ & $15.75 \pm 1.29^{\mathrm{c}}$ \\
\hline NP $0.5 \mathrm{mg} / \mathrm{kg}$ b.wt & $86.92 \pm 7.2^{\mathrm{d}}$ & $95.11 \pm 8.6^{\mathrm{d}}$ & $122.11 \pm 11.01^{\mathrm{d}}$ & $13.23 \pm 1.24^{\mathrm{d}}$ \\
\hline $\begin{array}{l}\text { DIM } 10 \text { mg/ kg b.wt } \\
\text { DIM @CS-NP }\end{array}$ & $78.25 \pm 6.6^{\mathrm{a}}$ & $85.64 \pm 7.2^{\mathrm{a}}$ & $107.86 \pm 5.82^{a}$ & $11.47 \pm 1.02^{\mathrm{a}}$ \\
\hline $0.5 \mathrm{mg} / \mathrm{kg}$ b.wt & $78.23 \pm 7.0^{\mathrm{a}}$ & $85.62 \pm 7.8^{\mathrm{a}}$ & $103.88 \pm 10.17^{\mathrm{a}}$ & $11.43 \pm 1.07^{\mathrm{a}}$ \\
\hline
\end{tabular}

Values are expressed as mean \pm SD for six rats in each group. Values not sharing a common superscript differ significantly at $p<0.05$ (DMRT). a: Control group, b: DMB A positive control group, c: DMBA positive control group treatment with DIM $10 \mathrm{mg} / \mathrm{kg}$ b.wt, d: DMBA positive control group treatment with DIM@CS-NP 0.5mg/kg b.wt. 
Table 7: Effect of DIM and DIM@CS-NP on lipoproteins in plasma of control and experimental rats.

\begin{tabular}{lccc}
\hline Group & $\begin{array}{c}\text { HDL } \\
(\mathbf{m g} / \mathbf{d L})\end{array}$ & $\begin{array}{c}\text { LDL } \\
(\mathbf{m g} / \mathbf{d L})\end{array}$ & $\begin{array}{c}\text { VLDL } \\
(\mathbf{m g} / \mathbf{d L})\end{array}$ \\
\hline Control & $35.92 \pm 2.92^{\mathrm{a}}$ & $34.04 \pm 2.31^{\mathrm{a}}$ & $15.64 \pm 0.91^{\mathrm{a}}$ \\
DMBA & $22.12 \pm 1.84^{\mathrm{b}}$ & $96.16 \pm 8.44^{\mathrm{b}}$ & $26.02 \pm 1.03^{\mathrm{b}}$ \\
DMBA+DIM & & & \\
10 mg/ kg b.wt & $28.82 \pm 2.61^{\mathrm{c}}$ & $69.80 \pm 5.22^{\mathrm{c}}$ & $20.46 \pm 1.50^{\mathrm{c}}$ \\
DMBA+DIM@CS-NP & & & \\
0.5mg/kg b.wt & $31.01 \pm 2.83^{\mathrm{d}}$ & $46.71 \pm 3.23^{\mathrm{d}}$ & $17.38 \pm 0.95^{\mathrm{d}}$ \\
DIM 10 mg/ kg b.wt & $35.87 \pm 2.96^{\mathrm{a}}$ & $34.12 \pm 2.11^{\mathrm{a}}$ & $15.65 \pm 1.32^{\mathrm{a}}$ \\
DIM@CS-NP & & & \\
$0.5 \mathrm{mg} / \mathrm{kg}$ b.wt & $35.9 \pm 3.07^{\mathrm{a}}$ & $34.07 \pm 2.13^{\mathrm{a}}$ & $15.64 \pm 0.99^{\mathrm{a}}$ \\
\hline
\end{tabular}

Values are expressed as mean \pm SD for six rats in each group.

Values not sharing a common superscript differ significantly at $p<0.05$

(DMRT). a: Control group, b: DMBA positive control group, c: DMBA positive control group treatment with DIM $10 \mathrm{mg} / \mathrm{kg}$ b.wt, d: DMBA positive control group treatment with DIM@CS-NP $0.5 \mathrm{mg} / \mathrm{kg}$ b.wt.
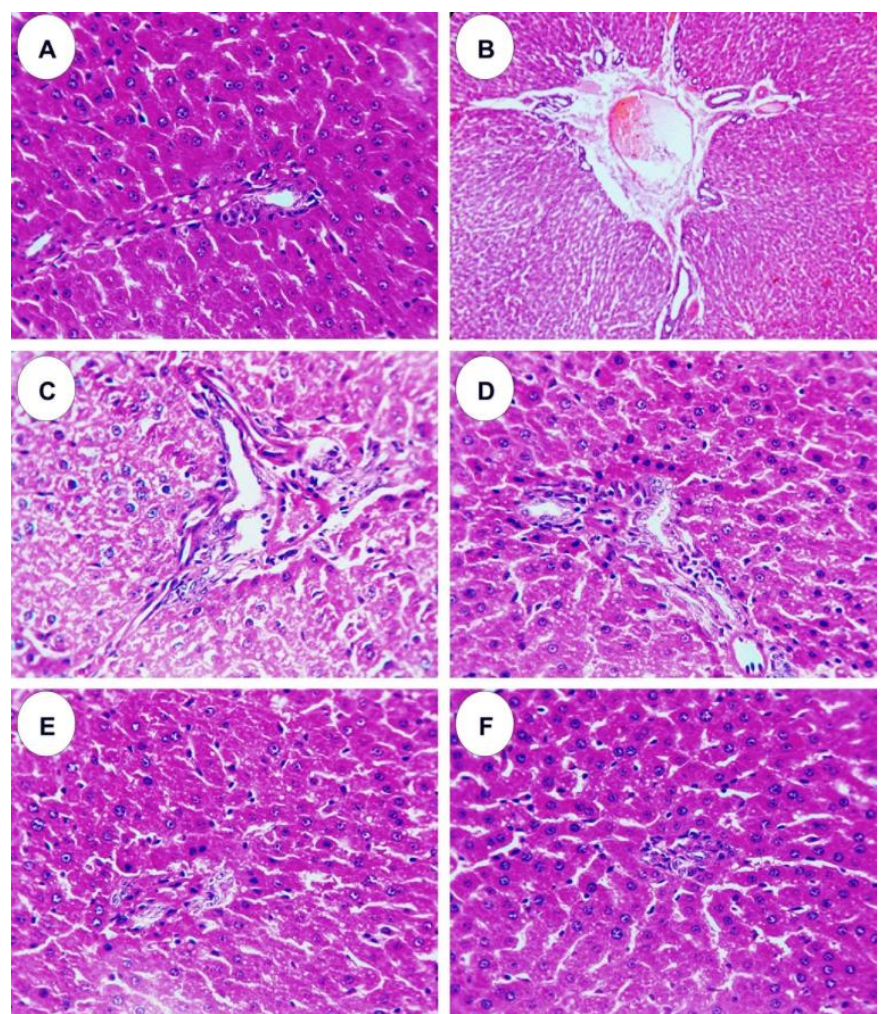

Fig. 2: Histopathological analysis of liver tissues of control and experimental rats. The Group 1 (A) control, Group 5 and 6 (E and F) DIM $10 \mathrm{mg} / \mathrm{kg}$ b.wt and DIM@CS-NP $0.5 \mathrm{mg} / \mathrm{kg}$ b.wt alone treated rats showed normal architecture of hepatocytes respectively; Liver tissues of $\mathrm{DMBA}(25 \mathrm{mg} / \mathrm{kg}$ b.wt $)$ induced rat Group II (B) DMBA-induced tumor bearing rats showed loss of architecture with nuclear pleomorphism and dilated sinusoids along with feathery degeneration; Group III (C) DIM $10 \mathrm{mg} / \mathrm{kg}$ b.wt treated rats showed portal triad with surrounding hepatocytes showing feathery degeneration with dilated sinusoids and mild necrosis; Group IV (D) DIM@CS-NP $0.5 \mathrm{mg} / \mathrm{kg}$ b.wt treated rats showed Portal triad with mild inflammation and markedly sinusoidal dilatation almost near normal architecture of hepatocytes.

\section{Effect of DIM and DIM@CS-NP on lipoprotein in plasma}

Table 7 represented the plasma of tumor bearing rats (Group II) showing increased levels of very low density lipoprotein cholesterol (VLDL- C) and low density lipoprotein (LDL-C), also decreased in high density lipoprotein cholesterol
(LDL-C). DIM@CS-NP $0.5 \mathrm{mg} / \mathrm{kg}$ b.wt (Group IV) more significantly reverted this altered lipoprotein levels than DIM $10 \mathrm{mg} / \mathrm{kg}$ b.wt (Group III). No significant changes were observed in all these parameters in drug control (Group V) and (Group VI) rats and control (Group I) rats.

\section{Histopathological changes in liver tissues (haematoxylin and eosin staining)}

Fig. 2 (A-F) shows, the histopathological changes of liver tissues of control and experimental rats. The group I (A) control, group V and group VI (E and F) DIM $10 \mathrm{mg} / \mathrm{kg}$ b.wt and DIM@CS-NP 0.5mg/ kg b.wt alone treated rats showed regular architecture of hepatocytes. Dissimilarly, in group II (B) DMBA induced tumor bearing rats were showed loss of architecture with nuclear pleomorphism and dilated sinusoids along with feathery degeneration. The group III (C) DIM $10 \mathrm{mg} / \mathrm{kg}$ b.wt treated rats were showed portal triad with surrounding hepatocytes showing feathery degeneration with dilated sinusoids and mild necrosis. The group IV (D) DIM@CS-NP $0.5 \mathrm{mg} / \mathrm{kg}$ b.wt treated rats showed portal triad with mild sinusoidal dilatation with markedly inflammation almost near normal architecture of hepatocytes. DIM@CS-NP $0.5 \mathrm{mg} / \mathrm{kg}$ b.wt (Group V) was found to be more effective as compare to DIM 10mg/ kg b.wt (Group VI).
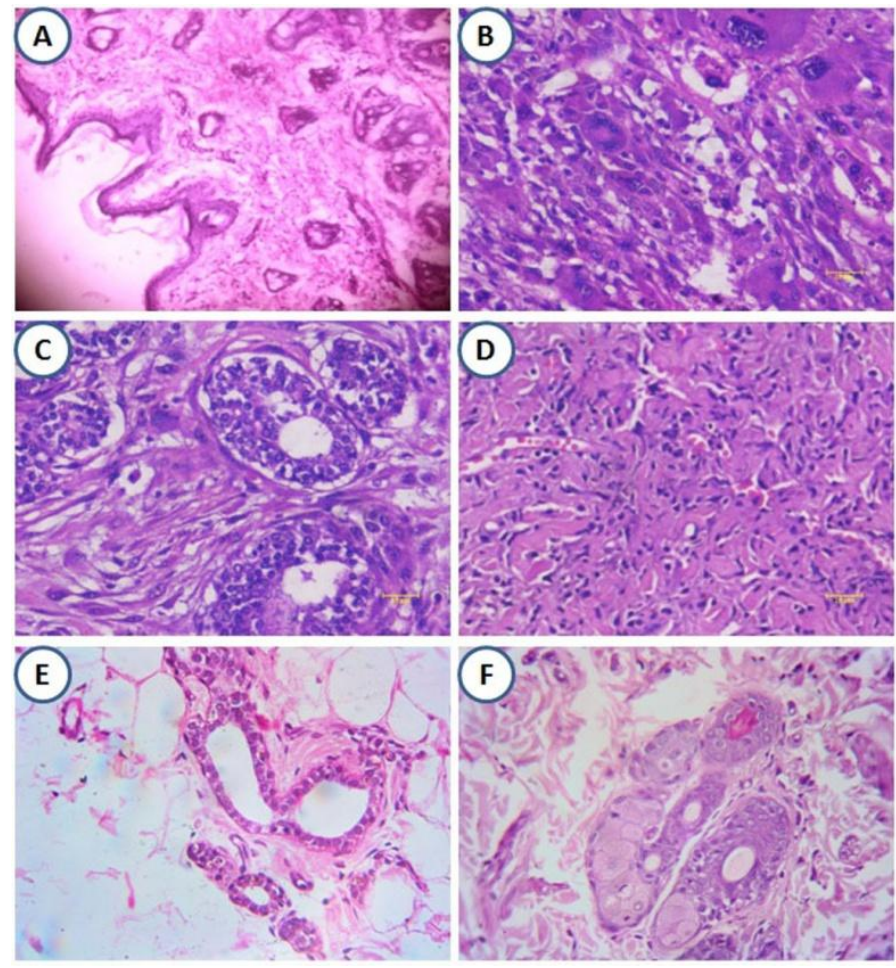

Fig. 3: Histopathological analysis of mammary tissues of control and experimental rats. The Group 1 (A) control, Group 5 and 6 (E and F) DIM 10 $\mathrm{mg} / \mathrm{kg}$ b.wt and DIM@CS-NP $0.5 \mathrm{mg} / \mathrm{kg}$ b.wt alone treated rats showing normal ductal epithelial architecture of the terminal epithelial buds; Group 2 mammary tissues of DMBA $25 \mathrm{mg} / \mathrm{kg}$ b.wt induced rat (B) showing invasive ductal carcinoma with abnormal cellular proliferation and infiltrated ducts; Group 3 mammary tissues of DMBA induced, treated with DIM $10 \mathrm{mg} / \mathrm{kg}$ b.wt (C) showing moderate ductal hyperplasia; Group 4 mammary tissues of tumor bearing rats treated with DIM@CS-NP $0.5 \mathrm{mg} / \mathrm{kg}$ b.wt (D) showed almost normal architecture of mammary tissue. 


\section{Histopathological changes in mammary tissues (haematoxylin and eosin staining)}

The histopathological changes in mammary tissues of control rats were shown in fig 3 (A), DIM $10 \mathrm{mg} / \mathrm{kg}$ b.wt (E) and DIM@CS-NP $0.5 \mathrm{mg} / \mathrm{kg}$ b.wt (F) rats showing usual ductal epithelial architecture of the terminal epithelial buds. In contrast, mammary tissues of DMBA (Group II) (B) induced rats showed invasive ductal carcinoma with abnormal cellular proliferation and infiltrated ducts. Followed by, mammary tissue of tumor bearing rats treated with DIM $10 \mathrm{mg} / \mathrm{kg}$ b.wt (C) (Group III) moderate ductal hyperplasia. Mammary tissue of tumor bearing rats treated with DIM@CS-NP 0.5 mg/kg b.wt (Group IV) (D) showed almost normal architecture of mammary tissue. As compared to DIM 10 mg/ kg b.wt (Group V), DIM@CS-NP 0.5 mg/kg b.wt (Group VI) was found to be more effective.

\section{DISCUSSION}

In treatment of cancer concern, chemotherapy is normally accompanied by toxic side effects, so restrictive quantity of the drugs able to be given to a patient. As a result, all the tumor tissue may not be uncovered to a lethal dose of the drug, by using Chitosan as a nanocarrier can develop the pharmacological properties of traditional chemotherapeutic (Maeda et al., 2000). Indeed, DMBA is imperative carcinogen that persuades mammary tumours in rats, which can, mimic human breast cancer clinically, morphologically and histopathologically. Fig. 1 shows the tumor level of DMBA, DIM and DIM @ CS-NP groups respectively. The DMBA induced group shows a well developed malignant tumor, at the treatment of DIM, reduced the tumor level. In this scenario, the treatment of DIM@CS-NP certainly reduced the tumor level as compared to DIM. Administration of DMBA in experimental model, leads to AhR/ARNT multifaceted complex, these complex attached to AhR specific genes and induces CYP1 genes transcription. Cytochrome P450 (Cyt P 450) which metabolize DMBA addicted to epoxide that, instantaneously forms DNA adducts, DNA adducts is a crucial incident in tumor formation.

Liver plays critical role in the activation and elimination of toxic xenobiotics. Xenobiotic certainly wield their pathological consequence through production of ROS, which is related to the cause of cancer. The metabolism xenobiotics are carrying out by the biotransformation enzymes for instance Phase I and Phase II enzymes, which act as a fundamental task by shifting biologically motionless compound into toxic metabolism compound (Mukherjee et al., 2006). Phase I enzymes, as well as Cyt P 450 dependent oxygenases metabolize DMBA to generate reactive compounds that are expected to be conjugated with hydro soluble groups by transferase including phase II enzyme such as GST and GR probably will add to DNA bases yielding covalent adducts. Besides, the metabolism activation and detoxification of DMBA in in vivo are known to occur primarily in the liver and also other organs including the mammary gland (Moor CJ et al.1986). In this present study, we noticed an elevated level of Cyt P450, Cyt-b5 and diminished levels of GST and GR in DMBA alone treated rats
Mathivadhani et al., (Mathivadhani et al., 2007) reported that, mammary tumor bearing rats illustrate increased levels of phase I enzymes and reduced activities of phase II enzymes. $13 \mathrm{C}$ on their metabolites are known to interact with the $\mathrm{Ah}$ receptor, these compounds induced together phase I and phase II drug metabolizing enzyme. While investigating the CYP genes, increased levels of various CYP 1 super families and decreased activity of certain other CYP protein were observed (Grubbs et al., 1995). Precise, DIM and DIM@CS-NP treated rats significantly altered simultaneously phase I and phase II enzymes levels as compared to DMBA induced rats. Similarly, oral administration of hesperidin was significantly decreased in phase I enzymes on DMBA induce mammary cancer. Conventionally, peroxidation of lipids within membranes and tissues causes the dripping of these lipids finally, delivery into the blood circulation, and as a upshot it leads to hyperlipidemia. The straight relationships among lipid peroxidation and subsequent alterations in lipid metabolism have previously been well established (Siddique et al., 2017). Together of benign and malignant proliferation of breast tissue in women has been coupled with the alteration of plasma lipids as well as lipoproteins. Previous studies states that, the risk of breast cancer is correlated with lipids and lipoproteins. Recently the modification of lipid fluidity of the tumor cell membrane was due to the increased levels of lipids (TC, PL, FFA, and TG) which can enhance the progression and proliferation of tumor cell (Franziska Baenke et al ., 2013). Our results also shows that elevated levels of lipids, (TC, PL, TG and FFA) lipoproteins (VLDL, LDL) in plasma, liver and mammary tissues and reduced in HDL in plasma when judge with control rats. Whereas, DIM@CS-NP were significantly reverted back to near normal, also high density lipoproteins (HDL) levels were decreased in cancer suffering rats.

The histopathological evaluations of liver tissues of DMBA induced tumor bearing rats showed defeat of architecture with nuclear pleomorphism and dilated sinusoids with feathery degeneration. In the contrary, DIM@CS-NP treated rats determined this change shows the strength capacity of anti lipidemic properties of the nano encapsulated compound. The additional prominent effect was observed in DIM@CS-NP treated rats by the normal architecture of hepatocytes with dilated sinusoids and moderate necrosis as compared to DIM. Therefore, our result suggests that the DIM@CS-NP has potential to protect liver from carcinogen (Lakshmi et al., 2015).

The histopathological assessment of mammary tissues of DMBA induced cancer bearing rats showed carcinomas exhibited invasive ductal carcinoma. In contrast, DIM@CS-NP treated rats exposed no sign of cellular proliferation and necrosis. The more effect was observed at DIM@CS-NP treated rats near the normal architecture of mammary tissue as compared to DIM. Therefore, it suggests that DIM@CS-NP exert chemotherapeutic potential on DMBA-induced mammary carcinogenesis for targeted drug delivery and sustained release manner (Isabella et al., 2016 and Lakshmi et al., 2004). 


\section{CONCLUSION}

In this study, speak polymeric nano particles are used for improved drug delivering system by using Chitosan, these nano particles as a carrier for the delivery of the anti-cancer drugs were established by successful loading DIM on to synthesized Chitosan nano particles. Our reports stated that, the beneficial influence of DIM@CS-NP enhanced the chemotherapeutic activity through the sustained release and target specific manner against DMBAinduced mammary carcinogenesis. The alterations of lipid, lipoproteins, phase I and phase II enzymes, supported by histopathological studies of liver and mammary tissues. Further studies required are rat the molecular level to elucidate the mechanism of DIM@CS-NP in DMBA induced mammary carcinogenesis.

\section{Acknowledgement}

Dr. K. Pandiyan, Associate Professor, Department of Inorganic Chemistry, University of Madras, Guindy Campus, Chennai-600 025, Tamil Nadu, India for nanoparticles synthesis and characterization studies.

Ethical approval: This study was approved by the Institutional Animal Ethics Committee (IAEC), regulated by the Committee for the Purpose of Control and Supervision of Experimental Animals (CPCSEA) (Reg No. 160/1999/CPCSEA and Proposal No. 1123).

Conflict of interest: The first author (Miss. S. Isabella) The corresponding author (Dr. S. Mirunalini) declares that there are no conflicts of interest.

Informed consent: This article does not contain any studies with human participants

Funding source statement: No funding source.

\section{REFERENCES}

Allain EC, Poon LS, Chan CS, Richmond W, Fu FC. Enzymatic determination of total serum cholesterol. Clin Chem, 1974;20: 470-5.

Arulmozhi V, Pandian K, Mirunalini S. Ellagic acid encapsulated chitosan nanoparticles for drug delivery system in human oral cancer cell line (KB). Colloids and Surfaces B Biointerface, 2013;110:313-320.

Carlberg I, Mannervik B. Glutathione reductase. Methods Enzymol, 1985; 113: 484-490.

Chan HY, Chen ZY, Tsang SCD, Leung LK. Baicalein inhibits DMBA-DNA adduct formation by modulating CYP1A1 and CYP1B1 activities. Biomed Pharmacotherapy, 2002;56: 269-275.

Duncan R. The dawning era of polymer therapeutics. Nat Re Drug Discov, 2003; 2: 347- 360.

Elzatahry AA , Mohy MS Eldin. Preparation and characterization of metronidazole-loaded chitosan nanoparticles for drug delivery application. Polym Adv Technol, 2008; 19:1787-1791.

Falholt K, Falholt W, Lund B. An easy colorimetric method for routine determination of free fatty acids in plasma. Clin Chim Acta, 1973; 46:105-111.
Folch J, Lees M, Stanley GH. A simple method for the isolation and purification of total lipids from rat tissues. J Biol Chem, 1957; 226 : 497-509.

Foster LB, Dunn RT. Stable reagents for determination of serum triglycerides by a colorimetric Hantzsch condensation method. Clin Chem, 1973;19:338- 40

Franziska Baenke, Barrie Peck, Heike Miess, Almut Schulze. Hooked on fat: the role of lipid synthesis in cancer metabolism and tumor development. Dis Model Mech, 2013; 6:13531363.

Friedewald WT, Levy RI, Fredrickson DS. Estimation of the concentration of low-density lipoprotein cholesterol in plasma, without use of the preparative ultracentrifuge. Clin Chem, 1972; 18:499-502

Grubbs CJ, Steele VE, Casebolt T. Chemoprevention of carcinogen- induced mammary carcinogenesis by indole-3-carbinol Anti cancer res, 1995; 15:709-716.

Habig WH, Pabst MJ, Jakoby WB. Glutathione Stransferases. The first enzymatic step in mercapturic acid formation. J Biol Chem, 1974;249:7130-7139.

Hanioka N, Jinno H, Nishimura T, Ando M. Changes in cytochrome P450 enzymes by 1,1-dichloroethylene in rat liver and kidney. Arch Toxicol, 1997;72 : 9-16.

Isabella S, Mirunalini S. Chemotherapeutic effect of 3,3'Diindolylmethane encapsulated chitosan nanoparticles on 7,12Dimethylbenz(a) anthracene induced mammary cancer - A dose dependent study. New Horizons in Translational Medicine, 2016; 3:18

Komenaka IK, Martinez ME, Pennington RE. Race and ethnicity and breast cancer outcomes in an under insured population. J Natl Cancer Inst, 2010;102:1178-1187.

Kuhajda FP. Fatty-acid synthase and human cancer: new perspectives on its role in tumor biology. Nutrition, 2000; 16: 202 208.

Kumar M, DeVaux RS, Herschkowitz JI. Molecular and Cellular Changes in Breast Cancer and New Roles of lncRNAs in Breast Cancer Initiation and Progression. Prog Mol Biol Transl Sci, 2016;144:563-586.

Lakshmi A, Subramanian S. Tangeretin, a citrus flavonoid attenuates oxidative stress and protects hepatocellular architecture in rats with 7, 12 - dimethylbenz(a)anthracene induced experimental mammary carcinoma. Journal of Functional Foods, 2015; 15: 339353.

Lowry OH, Rosebrough MJ, Farr AL, Randall RJ. Protein measurement with Folin-phenol reagent. J Biol Chem, 1951; 193:265275.

Maeda H, Wu J, Sawa T, Matsumura Y, Hori K. Tumor vascular permeability and the EPR effect in macromolecular therapeutics: a review. J Control Release, 2000; 65: 271-84.

Mathivadhani P, Shanthi P, Sachdanandam P. Effect of Semecarpus anacardium Linn. nut extract on mammary and hepatic expression of xenobiotic enzymes in DMBA-induced mammary carcinoma. Environ Toxicol Pharmacol, 2007; 23:328-334.

Moore CJ, Tricomi WA, Gould MN. Interspecies comparison of polycyclic aromatic hydrocarbon metabolism in human and rat mammary epithelial cells. Cancer Res, 1986; 46: 4946-4952.

Mukherjee S, Koner BC, Ray S, Ray A. Environmental contaminants in pathogenesis of breast cancer. Ind J Exp Biol , 2006; 44:597-617.

Nebert DW, McKinnon RA, Puga A. drug-metabolizing enzyme polymorphisms: effects on risk of toxicity and cancer. DNA Cell Biol, 1996; 15: 273-80.

Omura T, Sato R. The carbon monoxide binding pigment of liver microsomes. J Biol Chem, 1964; 239:2370-2378. 
Paltsev M, Kiselev V, Muyzhnek E, Drukh V, Kuznetsov I, Pchelintseva O. Comparative preclinical pharmacokinetics study of 3,3'-diindolylmethane formulations: is personalized treatment and targeted chemoprevention in the horizon? The EPMA Journal, 2013; 4(1): 25. http://doi.org/10.1186/1878-5085-4-25.

Siddique AI, Mani V, Arivalagan S, Thomas NS, Namasivayam N. Asiatic acid attenuates pre-neoplastic lesions, oxidative stress, biotransforming enzymes and histopathological alterations in 1,2-dimethylhydrazine-induced experimental rat colon carcinogenesis. Toxicol Mech Methods, 2017;11:1-15.

Welsch WC. Host factors affecting the growth of carcinogen-induced rat mammary carcinomas: A review and tribute to Charles Brent on Huggins. Cancer Res, 1985; 45: 3415-3443.

Wilson DE, Spiger MJ. A dual precipitation method for quantitating plasma lipoprotein measurement without ultracentrifugation. J Lab Clin Med, 1973; 82: 473-82.

Yangchao Luo TY, Thomas, Zi Wang, Pei Teng. Encapsulation of indole-3- carbinol and 3,3'-diindolylmethane in zein / carboxymethyl chitosan nanoparticles with controlled release property and improved stability. Food Chem, 2013;139: 224-230.

Zilversmit DB, Davis AK. Micro-determination of plasma phospholipids bytrichloroacetic acid precipitation. J Lab Clin Med, 1950; 35:155-159.

\section{How to cite this article:}

Isabella S, Mirunalini S. Protective effect of 3, 3'-Diindolylmethane encapsulated chitosan nanoparticles prop up with lipid metabolism and biotransformation enzymes against possible mammary cancer. J App Pharm Sci, 2017; 7 (03): 194-201. 